Original Scientific Article

\title{
IMPROVEMENT OF THE ANTIOXIDATIVE STATUS OF PIG OVARIES BY SELENOPYRAN TREATMENT
}

\author{
Desislava Vasileva Abadjieva ${ }^{1}$, Elena K. Kistanova ${ }^{1}$, Yordan $\mathrm{Marchev}^{2}$, Radka Nedeva$^{2}$, \\ ChaikaVaisberg ${ }^{1}$, Rossen Georgiev Stefanov ${ }^{1}$, Gennadiy Boryaev ${ }^{3}$, Mihail Nevitov ${ }^{3}$ \\ ${ }^{1}$ Institute of Biology and Immunology of reproduction-BAS, \\ bul. Tsarigradsko shose 73, p.c. 1113, Sofia, Bulgaria \\ ${ }^{2}$ Agricultural Institute, $B G-9700$ Shumen, Bulgaria \\ ${ }^{3}$ Penza State Agricultural Academy, RU - 2771 Penza, Russia
}

Received 2 June 2014; Received in revised form 31 July 2014; Accepted 10 August 2014

\begin{abstract}
Selenium is an essential micro-element in animal diet due to its high antioxidative properties. As a part of selenocystein it is an important constituent of the glutathione peroxidase (GPx) enzyme, which has a big importance for cell protection from oxidative damage. The aim of the present work was the investigation of the selenopyran effect on the antioxidative state of the pig ovary. The experiment was conducted with 18 gilts of Danube white breed randomly divided into two groups between 120 - 228 days of age. The animals received equal basal diets without selenium additives. The experimental gilts were injected once per month intramuscularly with oil solution of preparation selenopyran (9-phenylsymmetrical octahydroselenoxanthene) ensured $0.1 \mathrm{mgSe} / \mathrm{kg}$ live weight. After slaughtering, the ovaries were used for histological analysis and estimation of the selenium content in ovarian tissue by the atomic absorption spectroscopy method. The GPx activity in ovary homogenates using the colorimetric assay kit (BioVision) was measured. The expression of $\gamma$-glutamyl transpeptidase (GGT) in ovaries by immunochistochemical method was estimated. The selenopyran treatment leads to significant $(\mathrm{P}<0.05)$ increase of the selenium level in blood and non-significant $(\mathrm{P}>0.05)$ in ovarian tissue. Enhancement of GPx activity in the ovaries of experimental group was observed $(142.61 \pm 6.6$ versus $122.28 \pm 3.4 \mathrm{U} / \mathrm{gP}, \mathrm{P}<0.05)$. The GGT expression in the ovarian cortex cells, follicular fluid and in the erythrocytes of ovarian blood vessels in treated gilts was an evidence of active transport of glutathione from blood to the ovary tissue. The selenopyran treatment promotes the increase of the GPx dependent antioxidative defense in ovary of growing gilts.
\end{abstract}

Key words: pig ovary, selenopyran, glutathione peroxidase (GPx)

\section{INTRODUCTION}

Selenium is an essential and important trace element for reproductive biology and health due to its high antioxidative properties. The evidence of that is its wide distribution between tissues in the organism with varying density of storage: $30 \%$ in the liver, $30 \%$ in muscle, $15 \%$ in the kidney, $10 \%$ in the plasma, and the remaining $15 \%$ throughout other organs (1). Concentrations of free selenium are greatest in the renal cortex and the pituitary gland,

Corresponding author: Desislava Vasileva Abadjieva, $\mathrm{PhD}$ E-mail address: dessi 1@abv.bg

Present address: Institute of Biology and Immunology of reproduction- BAS, bul. Tsarigradsko shose 73, 1113, Sofia, Bulgaria

Copyright: $\subset 2014$ Abadjieva D. This is an open-access article published under the terms of the Creative Commons Attribution License which permits unrestricted use, distribution, and reproduction in any medium, provided the original author and source are credited.

Competing Interests: The authors have declared that no competing interests exist.

Available Online First: 14 August 2014

http://dx.doi.org/10.14432/j.macvetrev.2014.08.021 followed by the thyroid gland, adrenals, testes, ovaries, liver, spleen, and cerebral cortex $(2,3)$.

For the achievement of the optimal performances, the diets for the reproductive swine female require additional feed additives, including selenium. Selenium is included as a main active part in the selenoproteins, which are coded of 25 genes in mammalians and exert multiple actions on the endocrine, immune and inflammatory functions (4). The most important for reproduction and pregnancy are the six antioxidant glutathione peroxidases (GPxs), which play a pivotal role in reducing hydrogen peroxide $\left(\mathrm{H}_{2} \mathrm{O}_{2}\right)$ and lipid peroxides to harmless products (water and alcohols) $(5,6)$. As antioxidants, the GPxs help maintain membrane integrity, limit the propagation of oxidative damage to lipids, lipoproteins, and deoxyribonucleic acid (DNA) (5).

Data regarding selenium content related to the GPxs activity and female fertility are limited. 
The investigations in humans had shown that the unexplained infertility and low success rate in in vitro fertilization procedures are related to the decreased follicular selenium concentrations and lower GPxs activity $(7,8)$. In animals in vivo effects of selenium on ovaries were observed in beef cattle (9) and sheep (10), where parenteral administration of Se maximized fertilization rates of oocytes, but no mechanism of selenium action was discussed.

Little information is available about the effect of dietary supplemented selenium on the antioxidative status of pig ovaries. Recently there has been an increased interest to replace the inorganic selenium in the diet with organic. The selenium-containing compound designed to supplement is expected to have the following properties: hypotoxicity and biological availability of selenium in the composition. In this way, the organic selenium is more preferable, than sodium selenite. A number of research has reported increases of selenium serum levels and its positive effect on reproductive properties in sows fed by Se from an organic (Se-content yeast) versus inorganic (sodium selenite) source $(11,12,13)$. The main disadvantage of this organic source is the difficulty to do the precise dosages of the selenium, because the yeast accumulation of the selenium from medium depends on different factors and shows wide variability.

The present work aimed to investigate the effect of the organic selenium compound-selenopyran on the state of antioxidative defense in ovary of growing pigs.

\section{MATERIALS AND METHODS}

18 gilts of Danube white breed, ages between 120 - 228 days, were randomly divided into two groups, spread in 4 pig pens. The animals received equal basal diets without selenium additives. The animals were fed a basal diet with the following nutrition composition: $15.5 \%$ crude protein, $0.86 \%$ lysine, and $12.56 \mathrm{MJ}$ (metabolic energy) for the live weight $30-60 \mathrm{~kg}$ and $13.40 \%$ crude protein, $0.72 \%$ lysine and $12.83 \mathrm{MJ}$ for live weight $60-100 \mathrm{~kg}$. The content of $\mathrm{Se}$ in basal diet was $0.15 \mathrm{mg}$ per $\mathrm{kg}$ of forage.

The experimental gilts $(n=9)$ were injected intramuscularly with oil solution of selenopyran (9-phenyl-symmetrical octahydroselenoxanthene) once per month with dose $0.1 \mathrm{mg} \mathrm{Se} / \mathrm{kg}$ live weight. This organic source of selenium has a content of $24 \%$ of Se and has a lot of advantages. Besides the possibility for precise dosage of the compound, the toxity of it is lower than sodium selenite $\left(\mathrm{LD}_{50}=1600\right.$ $\mathrm{mg} / \mathrm{kg}$ against $\mathrm{LD}_{50}=3.25 \mathrm{mg} / \mathrm{kg}$ ). With regards to 166 its chemical structure, selenopyran plays a role in the selenium storage and liberates the selenium slowly according the needs of the organisms (14). After slaughtering, one ovary from each animal was used for the histological analysis. The second ovary was used for the estimation of the selenium content in ovarian tissue by the atomic absorption spectroscopy method in the State Laboratory for Food Control. The atomic absorption spectroscopy method by apparatus SpectrAA 220Z „Varian“ was applied for measuring the quantity of selenium in the ovary. Se was analyzed by standard addition, range $0-20 \mu \mathrm{g} / \mathrm{L}^{-1}$.

The blood for the investigation was obtained from sinus ophtalmicus. The analytical method used in this study for detection of Se in serum was a modified Classen and Bode method (15). It is a chemical technique based on complexing selenium with diaminobenzidine. The GPx activity in ovary homogenates using the colorimetric assay kit (BioVision, cat. no. K762-100) was measured, where the generated glutathione (GSSG) is reduced to GSH with consumption of NADPH. The decrease of NADPH (measured at $340 \mathrm{~nm}$ ) is proportional to GPx activity. The assay was used to measure all of the glutathione dependent peroxidases with a detection sensitivity of $\sim 0.5 \mathrm{mU} / \mathrm{ml}$ of GPx in samples.

For the preparation of histological sections, specimens were fixed in $4 \%$ paraformaldehyde (PFA) for $48 \mathrm{~h}$. All samples were embedded in paraffin and sectioned at an approximate thickness of $5 \mu \mathrm{m}$. Some sections (10 per ovary) were stained with $\mathrm{H} \& \mathrm{E}$ for histological observation. The expression of $\gamma$-glutamyl transpeptidase (GGT) in ovaries was estimated by immunochistochemical method using antirat-GGT polyclonal antibody (16). To detect the primary antibody, sections were treated with streptavidin/biotin complex, using a Vectastain Elite ABC kit (Vector Laboratories, Burlingame, CA, USA) according to the manufacturer's instructions and visualized with diaminobenzidine. The sections were counterstained with hematoxylin.

The statistical processing of the data was done by the STATISTIC computer programme (Stat Soft Inc., Ver.10.0). The one-way and regression analysis were done. Significance of mean differences was estimated by Student's t-test.

\section{RESULTS}

The Se content in blood and ovary is given in Table 1. Data shows that the selenopyran treatment leads to increase of the selenium level in blood $(\mathrm{P}<0.05)$. 
Table 1. Selenium content in blood and ovaries of pigs

\begin{tabular}{lll}
\hline Groups animals & Se blood, $\mathbf{~ m g} / \mathbf{L}$ & Se ovary, $\mathbf{~ m g} / \mathbf{k g}$ \\
\hline Experim. $(\mathrm{n}=9)$ & $0.086^{*} \pm 0.001$ & $0.047 \pm 0.004$ \\
Control $(\mathrm{n}=9)$ & $0.082 \pm 0.001$ & $0.042 \pm 0.003$ \\
\hline
\end{tabular}

*significant differences $\mathrm{P}<0.05$

Selenium content in ovarian tissues was higher in the experimental group compared to the control, but not significantly $(\mathrm{P}>0.05)$.

The significant increase $(\mathrm{P}<0.05)$ of the activity of GPx per $g$ total protein in the ovaries of experimental group was observed (Table 2). in blood and ovary, were high in the control group. The same value of $r$ was found for the relation of GPx activity and selenium content in blood in the experimental animals (Table 3). It seems that the activity of GPx in ovary is more dependent on the selenium content in the blood than in the ovary.

Table 2. Glutation peroxidase activity (GPx) in the ovary of growing gilts

\begin{tabular}{lllll}
\hline $\begin{array}{l}\text { Groups } \\
\text { animals }\end{array}$ & $\begin{array}{l}\text { Total GPx } \\
\text { in sample, U/ml }\end{array}$ & $\begin{array}{l}\text { Total } \\
\text { protein-TP,g }\end{array}$ & GPx, U/gTP & P \\
\hline $\begin{array}{l}\text { Experim. } \\
(\mathrm{n}=9)\end{array}$ & $1628.6 \pm 24.3$ & $11.5 \pm 0.4$ & $\mathbf{1 4 2 . 6 1} \pm \mathbf{6 . 6}$ & $\mathrm{P}=0.025$ \\
$\begin{array}{l}\text { Control } \\
(\mathrm{n}=9)\end{array}$ & $2205.4 \pm 115.5$ & $18.02 \pm 1.2$ & $\mathbf{1 2 2 . 2 8} \pm \mathbf{3 . 4}$ & \\
\hline
\end{tabular}

There were no significant correlations between the selenium content in blood and ovary and activity of GPx in ovaries (Table 3). Despite that the absolute values of the correlative coefficients $(\mathrm{r}=0.79)$, reflecting the relationship between activity of GPx in ovaries and the selenium content
Our analysis of GGT expression in the pig ovary has shown that GGT is not expressed in the oocytes, germinal epithelium or most stroma in control and experimental animals, but it presents in the ovarian cortex cells (Fig.1, A-B) follicular fluid (Fig.1, C-D) and in the erythrocytes of ovarian blood vessels (Fig.1, E-F) in treated gilts.

Table 3. Correlative relationship between activity of GPx in ovarian tissue and selenium content in blood and ovaries of growing gilts

\begin{tabular}{lcc}
\hline GPx & Se-ovary & Se-blood \\
\hline Experim. $(\mathrm{n}=9)$ & $\mathbf{0 . 3 0}$ & $\mathbf{0 . 7 9}$ \\
& $\mathrm{p}=0.621$ & $\mathrm{p}=0.110$ \\
Control $(\mathrm{n}=9)$ & $\mathbf{0 . 7 9}$ & $\mathbf{0 . 7 9}$ \\
& $\mathrm{p}=0.109$ & $\mathrm{p}=0.109$ \\
\hline
\end{tabular}



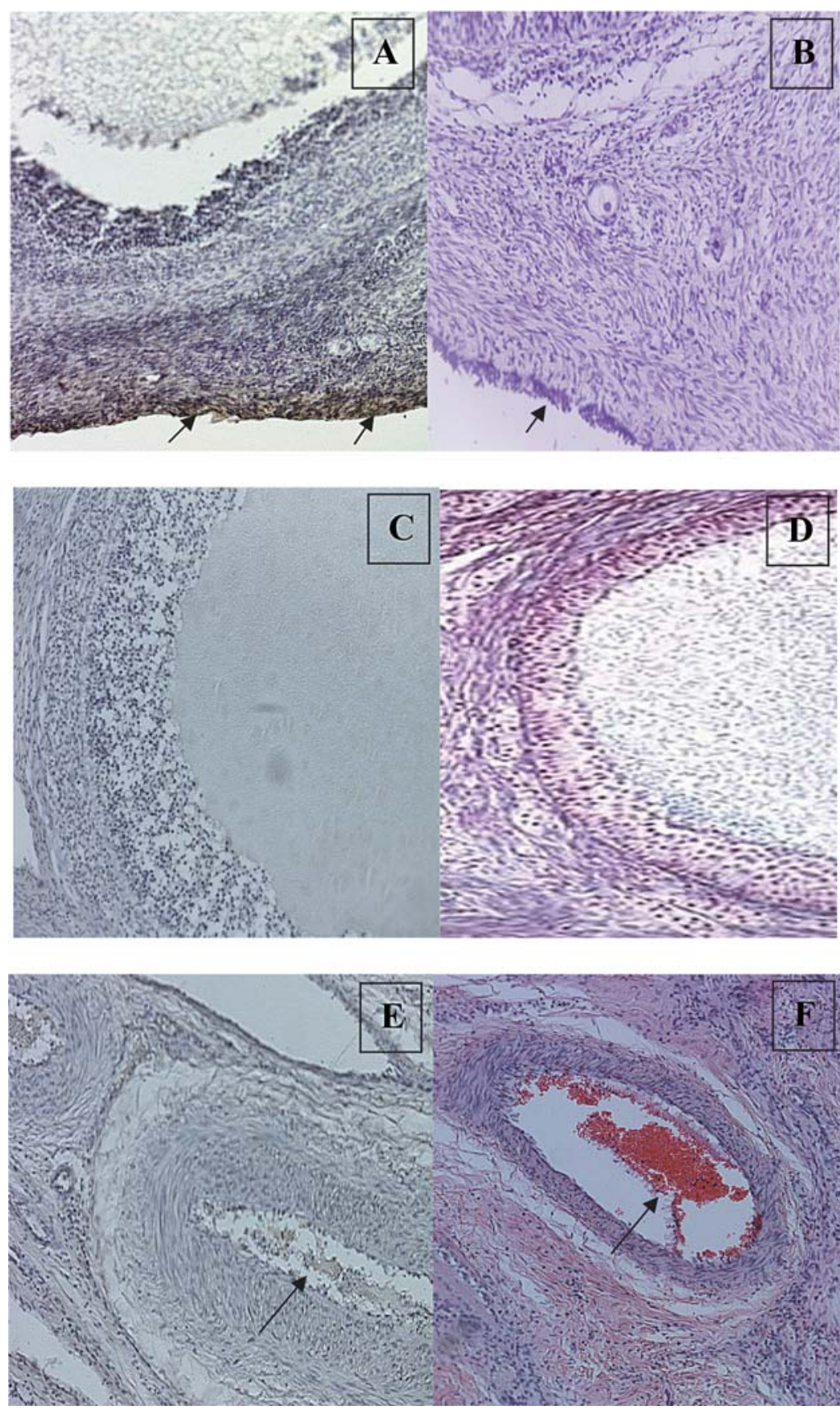

Figure 1. Localization of $\gamma$-glutamyl transpeptidase (GGT) in ovaries of growing pigs treated with selenopyran: A-immunochistochemical reaction in ovarian cortex cells; B-histological stained on ovarian cortex cells; C-immunochistochemical reaction in follicular fluid; D-histological stained on follicular fluid; E-immunochistochemical reaction on ovarian blood vessel; $\mathbf{F}$-histological stained on ovarian blood vessel

\section{DISCUSSION}

The most important metabolic role of selenium in mammalian species is its function in the active site of the selenoenzyme glutathion peroxidase and this enzyme, together with superoxide dismutase and catalase, protects cells against damage caused by free radicals and hydro- or lipoperoxides (17).

In the present study, the results show significant increase of the selenium level in blood $(\mathrm{P}<0.05)$ as well as higher activity of GPx $(\mathrm{P}<0.05)$ in the ovaries of the experimental 
Antioxidative status of pig ovaries by selenopyran treatment

group. Harrison and Conrad (1984), reported increased content of $\mathrm{Se}$ in whole blood, plasma and ovary (18). Whole blood Se was chosen in the present experiment as an indicator of circulating Se. It possibly reflects better the animal Se status, because more than $50 \%$ of the overall $\mathrm{Se}$ in circulation is presented in erythrocytes, mainly bound to hemoglobin (19). The studies in poultry (20) and goats (21), failed to show any effect of Se treatment on the activity of blood GPx. In our experiments we did not investigate the GPx activity in blood, but we observed the increase the GPx activity in ovaries.

Fortier et al. (2012), reported that the GPx in yellow bodies (CL) from ovaries of treated with Se pigs was greater that in the control group. Concerning the other main characteristics of $\mathrm{CL}$ including weight, diameter, total number or Se content, authors didn't find the treatment effect (22).

The important sign of the enhancement of the antioxidative defense is the activation of the glutathione transport that is the main constitutional part of GPx enzyme. The enzyme related to this process is $\gamma$-glutamyl transpeptidase (GGT). We found GGT expression in the ovarian cortex cells, follicular fluid and in the erythrocytes of ovarian blood vessels in treated gilts, which seems as an evidence of active transport of glutathione from blood to ovary tissue.

\section{CONCLUSION}

Enhancement of selenium content in blood (significant), in ovary (non-signi icant) and the GPx activity in ovaries as well as the evidence of activation of glutathione transport to ovary (by $\gamma$-GGT expression) has shown that the organic selenium compound - selenopyran promotes the GPx dependent antioxidative defense in the ovary of growing gilts.

\section{ACKNOWLEDGEMENTS}

The investigations were supported by the projects № DKOF7RP02/17 under the auspices of the Ministry of Education and Science of Bulgaria.

This work was supported by the grant № BG051PO001-3.3.06-0059, financed by the European Social Fund and Operational Programme Human Resources Development (2007 - 2013) and co-financed by the Bulgarian Ministry of Education and Science.

\section{REFERENCES}

1. Reilly, C. (2006). Selenium in food and health. New York: Springer.

2. Drasch, G., Mail, Der. S., Schlosser, C., Roider, G. (2000). Content of non-mercury-associated selenium in human tissues. Biol Trace Elem Res., 77, 219-230. http://dx.doi.org/10.1385/BTER:77:3:219

3. Kohrle, J., Jakob, F., Contempre, B., Dumont, J.E. (2005). Selenium, the thyroid, and the endocrine system. Endocr Rev., 26, 944-984.

http://dx.doi.org/10.1210/er.2001-0034 PMid:16174820

4. Gladyshev, Vadim N. (2006). Selenoproteins and selenoproteomes. Vadim Gladyshev Publications. Paper 36, p.102.

5. Rotruck, J.T., Pope, A.L., Ganther, H.E., Swanson, A.B., Hafeman, D.G., Hoekstra, W.G. (1973). Selenium: biochemical role as a component of glutathione peroxidase. Science, 179, 588-590. http://dx.doi.org/10.1126/science.179.4073.588 PMid:4686466

6. Hawkes, W. C., Alkan, Z. (2010). Regulation of redox signaling by selenoproteins. Biol. Trace Elem. Res. 134, 235-251.

http://dx.doi.org/10.1007/s12011-010-8656-7 PMid:20306235; PMCid:PMC2855032

7. Paszkowski, T., Traub, A.I., Robinson, S.Y., Mc-Master, D. (1995). Selenium dependent glutathione peroxidase activity in human follicular fluid. Clin. Chim. Acta, 236, 173-180. http://dx.doi.org/10.1016/0009-8981(95)98130-9

8. Ozkaya, M.O., Naziroglu, M., Barak, C., Berkkanoglu, M. (2010). Effects of multivitamin/ mineral supplementation on trace element levels in serum and follicular fluid of women undergoing in vitro fertilization (IVF). Biol. Trace Elem. Res., 139, p. 1-9.

http://dx.doi.org/10.1007/s12011-010-8637-x PMid:20180042

9. Segerson, E. C., F. A., Murray, A. L., Moxon, D., Redman, R., Conrad, H. R. (1977). Selenium/ vitamin E: Role in fertilization of bovine ova. J. Dairy Sci., 60, 1001-1005. http://dx.doi.org/10.3168/jds.S0022-0302(77)83978-7

10. Segerson, E. C., Ganapathy, S. N. (1980). Fertilization of ova in selenium/vitamin E-treated ewes maintained on two planes of nutrition. J. Anim. Sci., 51, 386-394. PMid:7440436

11. Mahan, D. C. (2000). Effect of organic and inorganic selenium sources and levels on sow colostrums and milk selenium content. J. Anim. Sci., 78,100-105. PMid:10682808 
12. Mahan, D. C., Peters, J. C. (2004). Long-term effects of dietary organic and inorganic selenium sources and levels on reproducing sows and their progeny. J. Anim. Sci., 82,1343-1358. PMid:15144075

13. Yoon, I., McMillan, E. (2006). Comparative effects of organic and inorganic selenium on selenium transfer from sows to nursing pigs. J. Anim. Sci., 84, 1729-1733.

http://dx.doi.org/10.2527/jas.2005-311

PMid:16775056

14. Boryaev, G. I., Kravchenko, Yu.V. (2006). Selenopyran is organic compound of selenium with original biological properties. International congress Euromedica, Hannover, Germany.

http://www.congress-euromedica.de/abstrakt/ broshuere2006.pdf.

15. Ibrishimov, N., Lalov, Hr. (1984). Clinical laboratory research in veterinary medicine. Zemizdat, Sofia.

16. Niida, S., Kawahara, M., Ishizuka, Y., Ikeda, Y., Kondo, T., Hibi, T., Suzuki, Y., Ikeda, K., Taniguchi, N. (2004). Gamma-glutamyl transpeptidase stimulates receptor activator of nuclear factor kappa B ligand expression independent of its enzymatic activity and serves as a pathological boneresorbing factor. J. Biol. Chem., 279, 5752-5756. http://dx.doi.org/10.1074/jbc.M311905200 PMid:14634009

17. Flohe, L. (1997). Selenium in peroxide metabolism. Med. Klin., 92, 5-7.

18. Harrison, J. H., Conrad, H.R. (1984). Selenium content and glutathione peroxidase activity in tissues of the dairy cow after short-term feeding. J. Dairy Sci., 67 (10), 2464-2470.

http://dx.doi.org/10.3168/jds.S0022-0302(84)81598-2
19. Giguere, A., Fortier, M.-E., Matte, J. J. (2005). Rapid, sensitive and versatile determination of selenium in different biological samples. Can. J. Anim. Sci., 85, 533-536. http://dx.doi.org/10.4141/A05-044

20. Payne, R. L., Southern, L. L. (2005). Comparison of inorganic and organic selenium sources for broilers. Poult. Sci., 84, 898-902.

http://dx.doi.org/10.1093/ps/84.6.898

PMid:15971527

21. Chung, J. Y., Kim, J. H., Ko, Y. H., Jang, I. S. (2007). Effects of dietary supplemented inorganic and organic selenium on antioxidant defense systems in the intestine, serum, liver and muscle of Korean native goats. Asian-australas. J. Anim. Sci., 20, 52-59.

http://dx.doi.org/10.5713/ajas.2007.52

22. Fortier, M.E.,Audet, I., Giguère, A., Laforest, J. P., Bilodeau, J. F., Quesnel, H., Matte, J. J. (2011). Effect of dietary organic and inorganic selenium on antioxidant status, embryo development, and reproductive performance in hyperovulatory firstparity gilts. J. Anim. Sci., 90, 231-240. http://dx.doi.org/10.2527/jas.2010-3340 PMid:21890500 